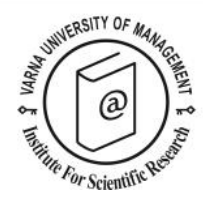

\title{
Job requirements in the hospitality industry: Technical or general skills? The dilemma for academic education
}

\author{
Lucia Varra ${ }^{1}$, Manuela Scioni ${ }^{2}$, \\ Laura Grassini ${ }^{*}$ and Antonio Giusti ${ }^{4}$
}

\footnotetext{
${ }^{1}$ Dipartimento di Scienze per l'Economia e l'Impresa, Università degli Studi di Firenze, Italy

2 Dipartimento di Scienze Statistiche, Università degli Studi di Padova, Italy

3 Grassini, Dipartimento di Statistica informatica applicazioni, Università degli Studi di Firenze, Italy. E-mail: laura.grassini@unifi.it

4 Dipartimento di Statistica informatica applicazioni, Università degli Studi di Firenze, Italy

* Corresponding author
}

\begin{abstract}
This paper identifies the professional profiles of graduates for job positions in the accommodation sector, in particular, whether specific skills of the position or skills related to the tourism sector are preferred. A conjoint design is applied, which presents the more realistic context of asking respondents to evaluate potential "product" profiles. Managers of accommodation facilities expressed their preferences on four hypothetical profiles of candidates for five job positions: receptionist, administrative clerk, human resources professional, web marketing specialist, revenue manager. Six attributes (academic degree and level, among others) are used to describe the candidate profiles. The data were analysed through a multinomial logit model and an ordinary least squares regression model that highlighted the preferred characteristics of the candidates for the considered job positions. The main findings show that recruitment in accommodation facilities looks at specialized skills and academic programmes appropriate for the specific job positions. Knowledge of the desired characteristics of graduates, which could affect a possible recruitment, is important for designing effective academic curricula.
\end{abstract}

Keywords: hospitality occupations, job requirements and competencies, choice-based conjoint, recruitment process, higher education

Citation: Varra, L., Scioni, M., Grassini, L. and Giusti, A. (2021). Job requirements in the hospitality industry: Technical or general skills? The dilemma for academic education. European Journal of Tourism Research 29, 2915 


\section{Introduction}

In the tourism sector, human resources (HR) play a vital role in maintaining a competitive position in the global market. However, the theme of HR in tourism is still presented in the literature in a fragmented way (Ballantyne, Packer \& Axelsen, 2009; Baum, 2007, 2015; Baum, Kralj, Robinson \& Solnet, 2016). The long held notion that tourism is characterized by low skills (Baum, 2006) has only been very gradually overcome, with an acceleration due to new theoretical approaches and paradigms, such as the "experience economy" (Pine \& Gilmore, 1999). In fact, in recent years, there has been an increasing interest in education for the tourism sector for a number of reasons: 1) greater awareness of the need for skilled personnel able to satisfy tourists looking for increasingly intense experiences; 2) greater attention by universities to collaborate with firms; and 3) the higher education system has recognized the importance of the tourism sector for both research and education activities.

Some studies have tried to understand whether there are gaps between the needs of the tourism industry and the knowledge acquired in educational pathways (Chiru et al., 2012; Connolly \& McGing, 2006; Cristou, 1999; Jahuari, 2006; Jaykumar, Leena \& Kandappan, 2014; Lupu, Tănase, \& Nica 2014; Ruetzler et al., 2014; Zopiatis \& Constanti, 2007). Of concern is whether the educational skills offered by the Italian education system and, in particular, universities actually meet tourism operators' needs. Knowing the reasoning underlying employers' hiring decisions can enable higher education institutions to help graduates acquire the skills they need to be successful in the labour market. With respect to the tourism sector, it might be of worth to understand whether enrolling in a study programme which emphasizes skills in tourism may come at the expense of developing skills for specific job positions, when such specialized skills are offered by other academic programmes (e.g., accounting).

The aim of this research is to determine employers' criteria and preferences in selecting graduate candidates for specific job positions in the hospitality sector. This study is part of a multi-centre research project ELECTUS-Education-for-Labour Elicitation from Companies' Attitudes towards University Studies-which involves several Italian universities and different economic activities (Fabbris, Scioni \& Vaglini, 2015). Graduates' profiles are described by some attributes typically listed in a curriculum vitae (CV), such as the field of study, the graduation mark (or final grade) and work experience. Each attribute is intended to describe the skills acquired by the graduates during their study and professional background, including soft skills, which are so important for companies (Andrews, J., \& Higson, H., 2008; Humburg \& Van der Velden, 2015; Wessels, Du Plessis \& Slabbert, 2017). For example: a degree programme in Humanities allows the development of more generic skills (in addition to specialized knowledge and skills), such as the ability to communicate, write and critical thinking; a degree course in Engineering facilitates the capacity of problem analysis, practical application of knowledge, and so on.

So, a conjoint experiment was conducted to simulate employers' screening of graduates' CVs in order to decide which applicants to invite for a job interview. The reader should bear in mind that the study is based on a sample circumscribed to a specific area, the Tuscany region, where tourism is an important driver of the regional economy, producing almost 12\% of GDP (Irpet, 2019). Moreover, this study is one of the first investigations into how hotel managers choose their employees.

\section{Literature review}

The literature on tourism explicitly recognizes HR as a fundamental component of tourist services and tourism business performance (Baum, 2019; Bitner, Booms \& Tetreault, 1990; Elsharnouby \& Elbanna, 2021; Nickson, Baum, Losekoot, Morrison \& Frochot, 2003; Marques, Correia \& Costa, 2018; Sardo, Serrasqueiro, \& Alves, 2018; Schneider, Hayes, Lim and Raver, 2003). However, academic research 
considered the workforce theme as less relevant compared with other research topics like environment and technology (Ballantyne et al., 2009; Baum, 2007, 2015; Baum et al., 2016; Baum \& Szivas, 2008; Ladkin, 2011). Academic contributions are often diluted within several fields of study like management, education and service design (Baum et al., 2016), and the workforce is sometimes considered a constraint ("being given a certain workforce") rather than a key driver of competitiveness (Ballantyne et al., 2009; Nickson, Baum, Losekoot, Morrison \& Frochot, 2003; Poole \& Jenkins, 1997; Varela González \& García Gorazo, 2006).

This general situation is partly due to the belief, not yet completely overcome, that the tourism industry is characterised by low and/or prevalently "technical" skills (Baum, 2007; Shaw \& Williams, 1994; Westwood, 2002; Wood, 1997). This "low skills paradigm" lasted for a long time before being gradually integrated with the new concepts, such as "emotional intelligence" (Goleman, 1995; Hochshild, 1983; Khetjenkarn \& Agmapisarn, 2020; Marques, Correia \& Costa, 2018) and "economy of experience" (Pine \& Gilmore, 1999). Thus, the importance of HR skills has been more and more recognized (Baum, 2006). Hochshild (1983) stated that tourism employees are required to "manage emotions" for which "soft skills" are more generally required (Westwood, 2004; Ritzer, 2004). Moreover, with the paradigm of the "economics of experience" (Pine \& Gilmore, 1999), concepts move from service quality and customer satisfaction to customer delight (Ankor, 2012; Johnson, 1987; Purohit \& Purohit, 2013). In this respect, Bharwani and Jauhari (2013) and Carbone and Haeckel (1994) recognized “experience intelligence" (i.e., the interactive skills and interactions with other individuals) as a relevant factor to make customer experiences memorable. In the literature, the definition of "hospitality intelligence" is a broad and varied set of skills in tourism and it does not only refer to technical aspects (Aydin, Leblebici, Arslan, Kilic \& Oktem, 2005; Bharwani \& Jauhari, 2013; Goleman, 1995).

Finally, two other concepts emerge from the literature that reveal the need for higher skills in tourism. Nickson, Baum, Losekoot, Morrison and Frochot (2003) and Warhurst, Nickson, Witz and Cullen (2000) defined "aesthetic skills" as the ability to respond according to fashion or, especially in luxury hospitality structures, to make good conversation about politics, music, sports or the like. Furthermore, Ang et al. (2007) and Earley and Ang (2003) recognized the importance of the ability to enter into a relationship with different cultures ("cultural skills").

Moving on to empirical analysis, numerous studies have been carried out to detect the new skills necessary for success in tourism, more particularly in hospitality. Many scholars have highlighted the relevance of a positive approach to working for managers (Akrivos, Ladkin \& Reklitis, 2007; ChungHerrera, Enz \& Lankau, 2003; De Vos \& Soens, 2008; Kay \& Russette, 2000; Lent, Brown \& Hackett, 1994; $\mathrm{Ng} \&$ Pine, 2003). Examples include taking initiative, willingness to accept challenges, enthusiasm and energy, and resilience. Other important skills include the ability to negotiate, to effectively communicate and to actively participate in the development and maintenance of social networks with colleagues and customers (Akrivos et al., 2007; Chung-Herrera et al., 2003; De Fillippi \& Arthur, 1994; Kay \& Russette, 2000; Ladkin \& Juwaheer, 2000; Munar \& Montano, 2009; Ng \& Pine, 2003; Sewell \& Pool, 2010; Wessel, Du Plessis \& Slabbert, 2017).

The growing attention paid to skills by scholars is not matched with an equally extensive literature on the aspects of candidates' curricula preferred by employers (Ruetzler et al., 2014; Shariff, Kayat, \& Abidin, 2014). This lack of information has a strong impact on the training of graduates looking for employment in tourism, as well as on the importance of technical and/or general skills associated with the sector and deriving from the educational path and work experience. In other words, the knowledge and skills associated with a given job position go beyond those strictly required to operationally perform 
that role (i.e., the technical skills). This leads to two fundamental questions. The first one concerns the importance employers attach to the different areas of expertise (technical and general), and their ability to discriminate between them during the hiring process. The second question is aimed at the ability of university programmes to take into account the skills required in the tourism sector.

Regarding the first question, the importance of technical and general skills has been widely discussed in the recent literature, particularly with reference to the hiring process, although not specifically for the tourism sector. Results do not always agree: some authors recognize the predominant role of the technical skills (among others, Elish, O’Connell \& Smyth, 2010; Heijke, Meng \& Ris, 2003; Humburg \& van der Vender, 2015), while others highlight the role of soft, or general, skills (among others, Andrews \& Higson, 2008; Moy \& Lam, 2004; Teijeiro et al., 2013). For example, with reference to accounting graduates, some studies highlighted that even for such a specialized programme, graduates with more generic skills seem to have more opportunities (Jackling \& De Lange, 2009; Gammie, Gammie \& Cargill, 2002; Mohamed \& Lashine, 2003; Smith, Maguire \& Han, 2018), while other research pointed out the importance of technical skills (Altarawneh, 2015).

An old dilemma concerns the alternative between study and work experience in the field. A recent work (Kong, 2015) pointed out that previous work experience, although considered more important by students than employers, is not a "must" to look for a job, because employers consider the required experience to be very embedded. However, this point is controversial as other studies argued that professional expertise is associated with a higher probability to be employed (van der Velden \& Allen, 2011; Humburg \& van der Velden, 2013, 2015).

With reference to the adequacy of academic programmes, for some decades, scholars have tried to understand whether there are gaps between the needs of the tourism industry and educational programmes, although minor attention has been devoted to university education (Connolly \& McGing, 2006; Cristou, 1999; Jahuari, 2006; Zopiatis \& Constanti, 2007); it is only in recent years that this has been the subject of in-depth analysis, also with reference to various countries (Airey, 2008; Kučerová \& Gúčik, 2017; Lupu, Tănase, \& Nica 2014, Studnička \&Plzáková, 2017; Vodenska \& Mileva-Bozhanova, 2017). The persistent vision is that tourism is not an independent discipline, and, consequently, educational programmes integrate business content, humanities and social sciences, resulting in a lack of any "threshold" concepts and content considered indispensable to more clearly qualify the academic offer more (Hsu, Xiao \& Chen, 2017). In fact, and at least in Italy, the complexity of the tourism sector that calls for professionals with cross-sectoral skills has led to the design of academic programmes permeated by economic, historical, humanistic and socio-psychological subjects. Perhaps it could be more appropriate to provide graduates specialized in the various disciplines (accounting, marketing, etc.) though without a focus of knowledge on tourism.

In reality, employers' recruitment processes consider all these aspects (training, skills, experience, etc.) to be not only individually relevant, but also their combination in "profiles", which are examined and selected "jointly". In fact, employers are faced with "packages" of knowledge and experience from which they must choose in the two phases of the selection process (Humburg \& van der Velden, 2015): screening of the graduates' CVs and job interview. In the second stage employers bring out and/or assess the skills of the candidates directly, in the first stage they must decide on the basis of a mix of elements that are predictive of the knowledge, technical skills and general skills (such as, educational qualifications, final grade and work experience). 
Recognizing the link between curriculum attributes and the knowledge and skills possessed by candidates, recent literature has focused, through the technique of conjoint analysis, on understanding how employers behave during this hiring process both in general contexts (Biesma, Pavlova, von Merode \& Groot, 2007; Humburg \& van der Velden, 2015) and specifically in the tourism sector (Ruetzler, Baker, Reynolds, Taylor \& Allen, 2014). Conjoint analysis is part of the wider field of experimental studies, although it is still rarely used. Sun, Law and Zhang (2019) conducted a recent review of experimental studies in the field of tourism, examining 91 papers retrieved from ScienceDirect, Scopus, Web of Science (also integrated with Google Scholars). They reported that experimental studies in the tourism sector have been growing strongly in the last decade, although the methods applied are mainly limited to between subjects experimental design (Chou \& Chen, 2014; Lindberg \& Veisten, 2012). Conjoint experiments in tourism and hospitality sectors are still few, just 13 studies among the 91 examined.

The few existing studies conducted using conjoint methodology to investigate which candidates' attributes are favoured in a selection process, involving profiles generated by specific software on the basis of a limited number of attributes (educational qualifications, final grade, etc.) and levels (e.g., for qualifications - degree, master, $\mathrm{PhD}$, etc.), have not given univocal results. Possible reasons are: attributes do not refer to a specific job (Humburg \& van der Velden, 2015), even when they concern the tourism sector (Ruetzler, Baker, Reynolds, Taylor \& Allen, 2014), or, conversely, attributes are specific for a given job position or economic sector and, therefore, results are not comparable (e.g., Di Stasio, 2014, for an entry-level position in the information and communications technology, ICT, sector). To the best of our knowledge, there are no comparative studies on the main job positions in the tourism sector.

\section{Some significant job positions in the accommodation industry}

Considering the skills needed by companies led to the identification of five job positions for the empirical analysis: receptionist, revenue manager, human resource professional, web marketing specialist, and administrative clerk. In our opinion, it is interesting to investigate these job positions as they include both traditional roles characterized by broad tasks (i.e., receptionist) and more innovative and specialized roles (i.e., web marketing specialist, revenue manager). Furthermore, as this survey is part of the wider ELECTUS survey research project, the job positions have been selected trying to maintain a common framework, albeit addressing different economic sectors. In detail, the aim was to include one entry-level job position for each the following areas: administrative, human resource, marketing, information technology (IT), and commercial.

\section{The receptionist}

Interest in front office staff stems from the importance and range of activities performed (Baronene, 2010). The front office worker position holds a plurality of lists: a consultant, who directs customers towards products and services; an analyst, who can understand customer needs and turn them into buying motivations; a marketing expert, who is a collector of input from the customer; a producer, as a process supervisor for the provision of the service; and a mediator between customers' and company's interests. Baum and Devine (2007), reporting the studies of Vallen and Vallen (2000), stated that front office staff need both soft and technical skills, such as interpersonal skills, communication skills, ICT and foreign languages. In addition, Baum and Odgers (2001) stressed that recruitment is guided by the search for these skills and not for specific training or work experience. 


\section{The revenue manager}

The professional profile of the revenue manager has acquired increasing prominence in the last 25 years (Anderson \& Xie, 2010). The revenue manager, whose task is to maximize revenue by identifying the right price at the right time for the right customer (Kimes, 1989; Kimes \& Wirtz, 2002), increasingly has a strategic professional profile that is not merely operational (Abrate \& Viglia, 2016). The job assumes knowledge of market demand, price policies, accounting and information management techniques (Upchurch, Ellis \& Seo, 2004). Cetin, Demirciftci and Bilgihan (2016) identified four categories of skills: personal (social and cognitive), generic, technical and ethical competencies. A wide range of skills from behavioural to operational aspects - is also recognized in Kimes (2011). Revenue managers' skills have now become even more complex because of the increasing use of social media instruments (Noone, McGuire \& Rohlfs, 2011). Cornell University School was the first college to offer university courses in revenue management, in 1994, with a practical and interactive approach (Anderson, Kimes \& Carrol, 2009). Today, the training of this profile is mainly provided by professional master's programmes.

\section{The human resource professional}

The human resource professional is "competent" to the extent that they can create a competitive advantage for the organization (Pfeffer, 1994; Ulrich, 1987). Consequently, Ulrich, Brockbank, Yeung and Lake (1995) identified three clusters of skills: knowledge of business, human resource functional expertise (i.e., staffing, performance appraisal, development) and managing change (i.e., vision, communication skills, influence skills, problem solving). Sincoff and Owen (2004) indicated the human resource strategic role, compensation, equal employment opportunity, organizational development and communication. Apparently, the skills depend very much on the areas of responsibility assigned to the human resource professional and by the training system in the country. In a cross-country study, the World Federation People Management Association has highlighted the difficulty to define unique competencies and, accordingly, has drawn well-defined indications for the curriculum of a human resource professional (Brewster, Farndale \& von Ommeren, 200o).

\section{The web marketing specialist}

The web marketing specialist embraces a plurality of activities (Batinić, 2015) using ICT, together with traditional practices, to achieve marketing results (Chaffey, Ellis-Chadwick, Mayer \& Johnston, 2009) in terms of customer acquisition, maintenance and satisfaction. The core features are: "consumer databases, interactivity, the ability of direct response to all forms of marketing activities and measurement of the effects of marketing activities" (Batinić, 2015, p. 35). These activities have been creating increasing opportunities for graduates in business administration from the 1970s onwards (Mitchell \& Strauss, 2001). Hence, many business schools include them in their academic programmes, with courses on database design, customer relationship management, and website design (Mitchell \& Strauss, 2001). Universities would therefore be justified in creating programmes entirely dedicated to web marketing, with a higher number of credits for such technical aspects (Mitchell \& Strauss, 2001).

Questions pertaining to the web marketing skills required by the market and issued by university programmes are part of the more general debate on the requirement of IT skills in hospitality (Abduljabbar Al-Taai, 2019; Cobanoglu, Dede \& Poorani, 2007; Garbin Praničević \& Mandić, 2020; Gonzalez, Gasco \& Llopis, 2019; Ip, Leung \& Law, 2011). On this point, there are still conflicting research findings between the demand for specialized skills and certifications of IT, and an integration of knowledge and skills of IT in the various professional areas (front office, marketing, etc.) (Cobanoglu et al., 2006). 
The administrative clerk

The traditional figure of the clerk in the tourism sector is increasingly enriched with areas of responsibility and skills due to the following factors: 1 ) a growing need to monitor internal and external variables (Cegarra-Navarro, Martinez-Martinez, Ortega Gutiérrez \& Leal Rodrìguez, 2013; Harris \& Mongiello, 2001; Phillips \& Louvieris, 2005); 2) the emergence of new issues, such as instances of social responsibility that require companies to measure their performance and draw up sustainability reports (Coles, Fenclova \& Dinan, 2013; Moscardo \& Benkendorff, 2015; Singal, 2014; Torugsa, O’Donohue \& Hecker, 2013); and 3) stringent regulatory and technological adjustments. New skills and knowledge are, therefore, required for both new hires and experts (Hartman, Bentley, Richards \& Krebs, 2005). In particular, the technological skills should be integrated into traditional educational paths related to office work (Hartman et al., 2005). The options for university training are between creating functional curricula, specific to accounting, programming and control, or the enhancement of generic skills on hospitality, complemented by practical activities related to office tools and applications.

In conclusion, universities face challenges to adequately respond to the recruitment requirements of the hospitality sector. The alternatives are between a possible combination or choice between two types of programmes offered: a "functional programme" with skills developed in specific areas of the company (marketing, IT, human resource management) and a "market/product-based programme", that is, niche courses on some specific sectors, such as hospitality and tourism.

\section{Methodology}

The graduate recruitment process is commonly divided into two steps (Humburg \& van der Velden, 2015). In the first step, employers screen graduates' CVs in order to decide which applicants to invite for a job interview. Secondly, after the job interview, employers make the hiring decision. In this first phase, without directly knowing them, employers have to rely on the candidates' attributes described in the $\mathrm{CVs}$, speculating on some possible correlation with the required characteristics for the job position in question (Humburg \& Van der Velden, 2015).

Taking into account the five job positions described in Section 3, the first step of the recruitment process (i.e., the curriculum-based selection) is simulated by a conjoint experiment. Despite requiring longer times than traditional surveys based on simple questionnaires, this methodology produces more informative outcomes. Rather than directly ask respondents what they prefer or what characteristics they find most important in a "product", conjoint analysis presents a more realistic context of asking respondents to evaluate potential "product" profiles.

Respondents were presented with some hypothetical job applicants (specifically four alternative profiles) who differed in important attributes. By asking respondents to choose the hypothetical graduate they preferred, they were forced to trade off some characteristics for others. This trade-off situation simulated a very realistic decision-making environment, which is often missing with a standard survey questionnaire. To refine our analysis, respondents were asked to rate the four profiles on 1 to 10 rating scale.

Conjoint analysis is a widely used method for analysing choice processes (Green \& Srinivasan, 1978); it resembles an individual's decision process and is based on a decompositional approach, in which the alternatives presented to the respondent are described by a set of characteristics (attributes). In choicebased conjoint analysis, each respondent should choose one or more alternatives in a small predesigned set, called "choice set". Thus, choice-based conjoint analysis involves discrete choices instead of 
preference judgements, such as in traditional conjoint analysis. Under this framework, the utility $U_{i j}$ of the alternative $j$ for the individual $i$ can be expressed as:

$$
U_{i j}=V_{i j}+\varepsilon_{i j}
$$

where $V_{i j}$ is an observed component, such as the evaluation of the alternative, and $\varepsilon_{i j}$ is the error term. The $i$-th individual will choose the $j$-th alternative if the associated utility is greater than the other alternatives' utilities in the same choice set $S$ (McFadden, 1974):

$$
U_{i j}>U_{i a} \forall a \neq j \in S \text {. }
$$

If it is assumed that $\varepsilon_{i j}$ are independently and identically distributed Gumbel-distributed variables with o location parameter, the probability $p_{i j}$ that the individual $i$ chooses the alternative $j$ is given by:

$$
p_{i j}=\frac{\exp \left(V_{i j}\right)}{\sum_{a}^{A} \exp \left(V_{i a}\right)} .
$$

The $V_{i j}$ are assumed to be linear functions in the $K$ attributes describing the alternative $j$-th; thus, $V_{i j}=$ $\sum_{k=1}^{K} \beta_{i k} X_{i j k}$, where $X_{i j k}$ assumes o/1 according to the absence/presence of the $k$-th attribute in the alternative. The model is multinomial logit, and the unknown parameters are jointly estimated via the maximum likelihood method (Louviere, Hensher \& Swait, 200o).

Rating data (i.e., value judgements attributed to the alternative) can be analysed using ordinary least squares (OLS) multiple regression. Even if data are collected on a non-metric scale, OLS multiple regression can be considered a reliable estimation procedure. Indeed, it was demonstrated in the literature (Carmone et al., 1978; Cattin \& Witting, 1982), that it provides parameter estimates similar to a non-metric estimation procedure such as MONANOVA.

Both in the case of the logit model and the OLS model, from the parameters $\beta$ s, the relative importance

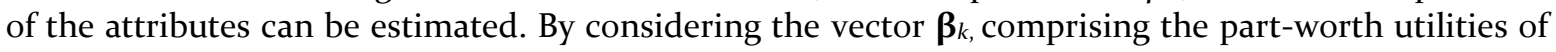
the $n_{k}$ levels of the $k$-th attribute, the importance index $R I_{k}$ of the attribute $k$ is:

$$
R I_{k}=100 \frac{\max \left(\beta_{k}\right)-\min \left(\beta_{k}\right)}{\sum_{w=1}^{K}\left(\max \left(\beta_{w}\right)-\min \left(\beta_{w}\right)\right)}
$$

From the analysis, the ideal profile is identified by considering the combination of the attribute levels with the maximum utility.

Regarding the use of experimental and discrete choice models in analysing the recruitment process in the tourism industry, the recent review by Sun, Law and Zhang (2019) found only the paper by Ruetzler, Baker, Reynolds, Taylor and Allen (2014). In contrast to Ruetzler et al. (2014), the present study reports the results of a wider investigation, and it is aimed at typical job positions of the hospitality industry. Moreover, the academic programme is intended as a proxy of the specific skills possessed by the candidate.

\section{Empirical analysis: research questions, survey design and data collection} Specific aims of the conjoint analysis

In the comparison of the five job positions - as done by Humburg and van der Velden (2015) and differently from Villosio (2010) - only CV attributes that were the result of graduates' human capital 
investment were included, excluding variables such as age, gender or ethnicity to make the employers' evaluation value-free and avoid hypothetical bias. The six attributes were: Degree Programme, Degree Level, Final grade, Foreign language skills, Work experience, Willingness to travel (Table 1).

Three specific issues were considered.

1) The central point of the research concerns the extent to which a course in tourism is attributed differing importance in consideration of different job positions. As discussed so far (see the literature review), the complexity of the tourism sector is also reflected in the hospitality industry, which also requires specialized professionals, so much so that some activities are outsourced (e.g., revenue management). Furthermore, our interest is to understand whether, in the selection of CVs, the accommodation industry prefers specialized degree courses rather than a degree in tourism. The analysis provides the extent to which a study programme is preferred over another; thus, even competitive academic programmes can be identified. As this study considered specific job positions, it is important to appreciate the importance of the match between the field of study and the job tasks. It is likely that graduates with a closer match have a higher probability of being selected because they may require a shorter period of training provided by the firm.

The types of degree programmes considered in the analysis included programmes that typically do not include topics useful for jobs in the tourism industry. On the other hand, this study is a part of a wider research on several economic sectors, in which the questionnaire had a minimal common structure. Therefore, it is expected that some academic degrees will not be selected by respondents who were informed about the educational objectives of the degree courses through a short description provided with the questionnaire (i.e., the description of the "classes"). In detail, in Italy, academic programmes sharing general educational objectives are grouped into "classes". Universities must comply with some national requirements for each class. Degrees belonging to the same class have the same legal value. With reference to tourism, the Italian university system provides a three-year first level (undergraduate) programme in Tourism sciences (class L15 Scienze del turismo), and a two-year second-level programme in "Design and management of tourist systems" (class LM49 Progettazione e gestione dei sistemi turistici). Analysing data from the 2016-17 undergraduate programmes, Giusti and Grassini (2017) identified four main curricula: 1) managerial studies; 2) art and humanities; 3) foreign languages and humanities; and 4) studies of territory (geographic information systems, agricultural economics, and social sciences). Two profiles characterized the master's programmes: one is more technical with informatics, geography, and managerial sciences, while the other is more traditional with managerial and law sciences, foreign languages, and economic history and theory. Moreover, it can be hypothesized that employers know the degree courses offered by the universities from already hired staff, as companies and universities share the same territory.

2) The discussed "low skill" paradigm that is still widespread in tourism, suggests investigating whether there is any preference for the first- or second-level degree. In this regard, some scholars suspected the concavity of the occupational production function with respect to individuals' skill level (Humburg \& van der Velden, 2015). The HR position might be an exception, as a second-level degree might be a preferential requirement because the HR office can acquire more credibility and authority among the employees. However, Villosio (2011) found a very small difference offset by brief work experience.

3) Another concern was whether work or internship experience in the tourism sector is a preferential requirement for recruitment. Work and internship experience were tested separately in the model, as the jobs proposed are junior positions in the organization. From an employer's point of view, relevant work experience may not be only a signal of graduates' occupation-specific skills, "but also one of 
general productive factors such as punctuality, attitudes towards hierarchical settings, and familiarity with work-life in general" (Humburg \& van der Velden, 2015, p. 31). From the academic's point of view, an internship agreement gives more visibility of the university to the community. Moreover, it may identify potential subjects of common interest and could provide feedback concerning the quality of education and suggestions for curricula updating; however, the search for an appropriate internship may be a complicated task because host organizations have become extremely selective, especially if the internship will result in a hiring.

The other attributes (final grade, willingness to travel, knowledge of foreign languages) were included in the experiment to complete the evaluated profiles. Moreover, the final grade may be considered as a proxy of the graduates' capacity to learn. Finally, a willingness to travel and foreign languages may be less important in a back office job (e.g., back office clerk).

\section{Survey design and data collection}

The survey constitutes a part of the multi-centre research project ELECTUS, which involves several Italian universities, to understand which characteristics employers value the most in the recruitment of young graduates. Several economic activities are covered within the project. The present survey, reserved for the tourism sector, was conducted using a computer-assisted web interviewing system. Data was collected using the Sawtooth Software that enables a choice-based conjoint experiment (Sawtooth Software, 2017).

Each respondent was asked to select the best among four possible profiles of candidates for each specific job position as the closest to the ideal candidate. Moreover, respondents were asked to assign a score between 1 and 10 to each profile they were called to evaluate. The attributes used to describe the possible candidates are reported in Table 1 . The number of attributes on the profiles is six, which is well below the limit of 10 attributes advised in the literature in order to limit the information processing burden on respondents (De Shazo \& Fermo, 2002). The attributes and their levels were selected because they can be considered a result of graduates' human capital investment, based on a literature review and the elicitation of experts' opinions through a focus group. The levels were chosen to be realistic and informative and to provide enough variations. The focus groups were conducted within the overall ELECTUS project and not just for the present analysis of the hospitality industry (see, for example, Mariani, Marletta \& Zenga, 2019). The focus group saw the participation of almost ten experts usually involved in hiring processes, such as entrepreneurs, employers, HR managers and representatives of employers' organizations. After a brief description of the research project and the methodology applied to carry out the survey, the focus group developed around two questions. The first one intended to investigate precisely which characteristics in the CV are evaluated in selecting a candidate, while the second was aimed at understanding whether some company and/or employer attributes may influence the hiring process.

Table 2 shows a typical vignette with the four alternative profiles (the choice set) submitted to the respondents. The question was, "Imagine that you are interested in recruiting a person for the position of (...). Which of the four profiles displayed on the screen would you invite for a job interview as being the closest to your ideal candidate?" In addition, each respondent was asked to rate each profile in the choice set, using a 1 to 10 rating scale. 
Table 1. Attributes and attribute levels

\begin{tabular}{lcl}
\hline Attribute & \# levels & Levels \\
Degree programme & 10 & $\begin{array}{l}\text { Humanities, Education/Psychology, Tourism, Law/Political } \\
\text { sciences, Economics, Statistics, Engineering, Maths/Computer } \\
\text { science, Foreign languages, Communications }\end{array}$ \\
$\begin{array}{l}\text { Degree level } \\
\text { Final grade (66-110) }\end{array}$ & 3 & $\begin{array}{l}\text { First level, Second level, PhD } \\
<95,95-104,>104 \\
\text { Unable to engage in a dialogue with foreigners, Not fluent } \\
\text { communication with foreigners, Fluent communication with } \\
\text { foreigners } \\
\text { No experience, Some experience (even internship), Some } \\
\text { experience in tourism (even internship), Stable work for at least one } \\
\text { year (even if not in the tourism sector) } \\
\text { Work experience }\end{array} \quad 3 \quad \begin{array}{l}\text { Not willing, Available only for short trips, Even major transfers } \\
\text { Willingness to travel }\end{array}$ \\
\hline
\end{tabular}

The predesigned sets of four profiles were generated according to a near-orthogonal design (Sawtooth Software, 2017) through a heuristic algorithm called "Balanced overlap". It starts from the set of all possible alternatives and arranges them into choice sets according to the following principles: level balance (each level of an attribute is shown to respondents approximately an equal number of times), balanced overlap (a modest amount of level overlap among the alternatives in the same choice set was ensured), and orthogonality (attribute levels describing each alternative should be chosen independently of other attribute levels). No duplicate alternatives were allowed within the same task.

Table 2. Example of vignette submitted to respondents

\begin{tabular}{|c|c|c|c|c|}
\hline Attribute & Profile 1 & Profile 2 & Profile 3 & Profile 4 \\
\hline $\begin{array}{l}\text { Degree } \\
\text { programme }\end{array}$ & Tourism & Statistics & $\begin{array}{l}\text { Education/ } \\
\text { Psychology }\end{array}$ & $\begin{array}{l}\text { Maths/Computer } \\
\text { science }\end{array}$ \\
\hline Degree level & Second level & $\mathrm{PhD}$ & First level & Second level \\
\hline Final grade & $95^{-104}$ & $>104$ & $>104$ & $<95$ \\
\hline $\begin{array}{l}\text { Foreign } \\
\text { language }\end{array}$ & $\begin{array}{l}\text { Unable to engage } \\
\text { in a dialogue with } \\
\text { foreigners }\end{array}$ & $\begin{array}{l}\text { Not fluent } \\
\text { communication } \\
\text { with foreigners }\end{array}$ & $\begin{array}{l}\text { Fluent } \\
\text { communication } \\
\text { with foreigners }\end{array}$ & $\begin{array}{l}\text { Not fluent } \\
\text { communication } \\
\text { with foreigners }\end{array}$ \\
\hline $\begin{array}{l}\text { Work } \\
\text { experience }\end{array}$ & No experience & $\begin{array}{l}\text { Some experience } \\
\text { in tourism } \\
\text { (even internship) }\end{array}$ & $\begin{array}{l}\text { Some experience in } \\
\text { tourism } \\
\text { (even internship) }\end{array}$ & $\begin{array}{l}\text { Stable work for at } \\
\text { least one year }\end{array}$ \\
\hline $\begin{array}{l}\text { Willingness } \\
\text { to travel }\end{array}$ & None & $\begin{array}{l}\text { Even major } \\
\text { transfers }\end{array}$ & Only short trips & $\begin{array}{l}\text { Even major } \\
\text { transfers }\end{array}$ \\
\hline
\end{tabular}

A random design was implemented as it is more efficient in the case of asymmetrical designs (i.e., designs with attributes with different number of levels) as in our case (Kuhfeld et al., 1994). Overall, 250 choice sets were generated, each one containing four alternatives. Level balance was respected. Each of the ten levels of the attribute "Degree programme" occurred between 9.9\% and 10.1\% times. Each level of attributes with three levels (Degree level, Degree grade, Foreign language, Willingness to travel) occurred between $33.2 \%$ and $33.4 \%$ times. Finally, each of the four levels of the attribute "Work experience" occurred between $\mathbf{2 4 . 9} \%$ and $\mathbf{2 5 . 1} \%$ times. Each respondent performed five choice experiments, one for each job position. 
The survey was directed to accommodation facilities located in Tuscany with a minimum threshold quality for the service: three-star hotels and a similar analogous level for non-hotel firms. The population frame was derived by matching open data and the registry of the Chamber of Commerce of Tuscany's provinces. Preliminary contact with the companies was established via telephone; a call was needed to screen the companies and to obtain the email address of the reference person. The establishments were then contacted through the provided email address and presented with the research project and a link to the electronic questionnaire. Furthermore, reminders were sent by email but also directly by telephone.

Of the respondents, 218 (190 hotels and similar, and 28 other accommodation facilities) completed the questionnaire, with an overall response rate of $8.1 \%$ (10.5\% for hotels and similar). The higher response rate for hotels and residences is because this kind of accommodation facility has a structured organization with various functional areas and is therefore suitable for contributing to the research project. In fact, many questionnaires were not filled in because the respondents stated that they did not have those job positions in their firms. This was also confirmed by the size of the accommodations participating in the survey: just $45.4 \%$ had less than 10 employees versus $84.8 \%$ of the reference population.

Table 3. Personal characteristics of respondents

\begin{tabular}{lc}
\hline Demographic characteristics & $\%$ \\
\hline Gender & \\
Male & $47 \cdot 3$ \\
Female & 52.7 \\
Age & \\
$<40$ & 33.0 \\
$40-49$ & 34.9 \\
>50 & 32.1 \\
Education level & \\
Up to the higher secondary level & 56.0 \\
University or graduates or post-graduates & 44.0 \\
\hline
\end{tabular}

Table 4. Characteristics of accommodation facilities involved in the survey

\begin{tabular}{lc}
\hline Characteristics of the accommodation facilities & $\%$ \\
\hline Type of accommodation establishment & \\
Hotels and similar & 87.2 \\
Other accommodation facilities & 12.8 \\
Customers' origin & \\
Mostly foreign & 60.0 \\
Mostly Italian & 40.0 \\
Presence of specific job positions & \\
Receptionist & 96.3 \\
Administrative clerk & 75.7 \\
Revenue manager & 58.7 \\
Web marketing specialist & 44.9 \\
Human resource professional & 41.7 \\
\hline
\end{tabular}


The characteristics of the respondents are reported in Table 3, whereas Table 4 summarizes the structural features of accommodation establishments. A specific resource devoted to front office staff was present in almost all the accommodation facilities (96.3\%) but it did not occur for the other job positions. Thus, there was a self-selection of respondents depending on the presence of the five job positions in the accommodation structure.

\section{Results}

Since each attribute level is equally likely to occur in the choice-based conjoint design, its relevance can be assessed by the proportion of times that profiles with that level have been chosen. Table 5 shows the most chosen programmes for the five job positions. An education in tourism is preferred for some of the tourism industry's typical job positions: receptionist, web specialist and revenue manager. However, an additional degree in foreign languages is indicated for receptionist, Communications for the web marketing specialist, and Economics for the revenue manager. By contrast, for two of the considered five positions, a Tourism education is not of worth: a degree in Economics is required for the administrative clerk, while a degree in Education or Psychology is indicated for the human resource professional.

These findings are more precisely expressed by the parameters of the estimated multinomial logit model (Table 5). McFadden's pseudo $\mathrm{R}^{2}$ shows that the model fit is good, especially for the job position of receptionist. A degree in Tourism exhibits positive and statistically significant (at o.05 level) beta values for the positions of receptionist, web specialist, revenue manager, and, to a lesser extent, human resource professional. Statistics, Engineering, and Mathematics/Computer science are unattractive for a front office position, while Humanities and Education/Psychology are not attractive for the administration and accounting staff. Overall, all study programmes submitted to entrepreneurs' evaluations were relevant for at least one job position in tourism, except Humanities and Engineering. This result appears reasonable, since these two degree courses, for different reasons, are not primarily aimed at the tourism sector. The attributes "Degree level" and "the willingness to travel" had no significant effect across job positions, so they were dropped from the table.

As expected, there is no difference among different degree levels, confirming the mentioned "low skills" paradigm. Moreover, not even the HR professional proved an exception. Since the results of this conjoint experiment can be read as a reflection of already implemented behaviours, this means that entrepreneurs in the accommodation sector do not look at all at the degree level.

The effect of the attribute "Degree grade" is significant in more technical roles like administrative clerk, web marketing specialist and revenue manager. However, on average, having good grades had no additional effect on graduates' probability to be invited to a job interview for the job positions of receptionist and HR professional. On the other hand, knowledge of foreign languages and the possession of work experience (or internship, and not necessarily in the tourism sector) were required for each of the considered job positions, confirming to some extent Kong's (2015) findings.

In addition, Table 5 reports the index of attribute importance. For the job position receptionist, the most important attribute is the knowledge of foreign languages, closely followed by the degree programme. By contrast, work experience and degree grade are much less important. Administrative clerk, HR professional and revenue manager are characterised, albeit with some differences, by high importance for the attribute degree programme, followed at some distance by work experience. In particular, the job position of HR professional has the highest importance placed on degree programme. 
The job position of web specialist is characterised by closer levels of the following attributes: degree programme (at the first position), foreign language (at the second), and then work experience.

Table 5. Frequency of degree programmes (\%), estimated parameters of the logit model, importance of attributes (\%)

\begin{tabular}{|c|c|c|c|c|c|}
\hline Attribute/levels & Receptionist & $\begin{array}{c}\text { Administrative } \\
\text { clerk }\end{array}$ & $\begin{array}{c}\text { HR } \\
\text { specialist } \\
\end{array}$ & $\begin{array}{c}\text { Web } \\
\text { specialist } \\
\end{array}$ & $\begin{array}{l}\text { Revenue } \\
\text { manager }\end{array}$ \\
\hline \multicolumn{6}{|c|}{ \% frequency (bold: highest values) } \\
\hline \multicolumn{6}{|c|}{ Degree programme } \\
\hline Humanities & $23 \cdot 5$ & $5 \cdot 3$ & 18.2 & 11.0 & 9.8 \\
\hline Education/Psychology & 15.1 & 8.7 & 58.1 & 18.8 & 19.6 \\
\hline Tourism & 46.1 & 29.9 & 36.0 & 46.7 & 51.2 \\
\hline Law/Political sciences & 18.3 & 23.5 & 30.0 & 10.8 & 14.8 \\
\hline Economics & $25 \cdot 3$ & 60.2 & 19.8 & 25.8 & $43 \cdot 7$ \\
\hline Statistics & $14 \cdot 3$ & 29.6 & 17.1 & $24 \cdot 7$ & 30.8 \\
\hline Engineering & 10.3 & 18.9 & 5.0 & 18.9 & 14.0 \\
\hline Math/Computer science & 14.8 & 42.5 & 14.0 & 26.6 & 26.6 \\
\hline Foreign languages & 48.4 & 19.0 & 15.1 & 27.0 & 19.0 \\
\hline Communications & 31.3 & 16.5 & 41.1 & $39 \cdot 5$ & 22.4 \\
\hline \multicolumn{6}{|c|}{ Estimated parameters (bold: at least significant at o.o5 level) } \\
\hline \multicolumn{6}{|c|}{ Degree programme } \\
\hline Humanities & -0.1347 & -1.6799 & -0.2597 & -1.1317 & -1.3415 \\
\hline Education/Psychology & -0.6928 & -1.2090 & 1.6213 & -0.3226 & -0.3069 \\
\hline Tourism & 1.6602 & 0.4499 & 0.8026 & 1.2813 & 1.3586 \\
\hline Law/Political sciences & -0.3921 & 0.0737 & 0.4840 & -0.8688 & -0.4107 \\
\hline Economics & 0.1563 & 1.7121 & -0.2569 & 0.1253 & 1.0814 \\
\hline Statistics & -1.1405 & 0.5406 & -0.3107 & 0.1151 & 0.4406 \\
\hline Engineering & -1.2128 & -0.1150 & -1.7730 & -0.4198 & -0.7467 \\
\hline Math/Computer science & -0.9887 & 1.0475 & -0.6482 & 0.2081 & 0.1907 \\
\hline Foreign languages & 2.2059 & -0.3228 & -0.5350 & 0.1715 & -0.1796 \\
\hline Communications & 0.5392 & -0.4926 & 0.8758 & 0.8415 & -0.0857 \\
\hline \multicolumn{6}{|l|}{ Final grade (/110) } \\
\hline$<95$ & -0.2585 & -0.1227 & -0.1512 & -0.4378 & -0.3894 \\
\hline $95-104$ & 0.0619 & -0.1444 & 0.0287 & 0.1734 & 0.1543 \\
\hline$>104$ & 0.1964 & 0.2671 & 0.1225 & 0.2644 & 0.2352 \\
\hline \multicolumn{6}{|l|}{ Foreign language } \\
\hline Unable to dialogue & -2.3893 & -0.3898 & -0.3562 & -0.9317 & -0.6725 \\
\hline Not fluent & 0.4626 & -0.1041 & 0.0113 & 0.1649 & 0.2126 \\
\hline Fluent & 1.9267 & 0.4939 & 0.3449 & 0.7668 & 0.4599 \\
\hline \multicolumn{6}{|l|}{ Work experience } \\
\hline None & -0.8981 & -1.0788 & -0.9378 & -0.8380 & -1.2187 \\
\hline Stage/work & 0.0708 & 0.1793 & 0.3120 & -0.0092 & 0.2234 \\
\hline Stage/work in tourism & 0.4668 & 0.2692 & 0.2820 & 0.4914 & 0.4416 \\
\hline Work at least one year & 0.3605 & 0.6303 & 0.3437 & 0.3559 & 0.5537 \\
\hline
\end{tabular}




\begin{tabular}{lccccc}
$\ln L($ model $)$ & -148.79 & -216.40 & -235.08 & -231.95 & -219.90 \\
$\ln L(\mathrm{o})$ & -302.21 & $-302-21$ & -310.53 & -310.53 & -300.83 \\
$p$-value LRT & $<0.0001$ & $<0.0001$ & $<0.0001$ & $<0.0001$ & $<0.0001$ \\
McFadden pseudo R ${ }^{2}$ & 0.508 & 0.284 & 0.243 & 0.253 & 0.269 \\
\hline Importance of attributes $(\%)$ & & & & & \\
\hline Degree programme & 35.8 & 53.1 & 60.1 & 39.4 & 43.3 \\
Final grade & 4.8 & 6.4 & 4.8 & 11.4 & 10.0 \\
Foreign language & 45.2 & 13.8 & 12.3 & 27.6 & 18.2 \\
Work experience & 14.2 & 26.7 & 22.7 & 21.6 & 28.5 \\
\hline
\end{tabular}

Table 6. Estimated parameters of the ordinary least squares model

\begin{tabular}{|c|c|c|c|c|c|}
\hline Attribute/levels & Receptionist & $\begin{array}{c}\text { Administrative } \\
\text { clerk }\end{array}$ & $\begin{array}{c}\text { HR } \\
\text { specialist }\end{array}$ & $\begin{array}{c}\text { Web } \\
\text { specialist }\end{array}$ & $\begin{array}{l}\text { Revenue } \\
\text { manager }\end{array}$ \\
\hline \multicolumn{6}{|c|}{ Estimated parameters (bold: at least significant at 0.05 level) } \\
\hline \multicolumn{6}{|c|}{ Degree programme } \\
\hline Humanities & -0.325 & -0.596 & -0.371 & -0.516 & -0.622 \\
\hline Education/Psychology & -0.262 & -0.691 & 1.191 & -0.266 & -0.499 \\
\hline Tourism & 0.590 & 0.465 & 0.464 & 0.702 & 1.021 \\
\hline Law/Political sciences & -0.096 & 0.082 & -0.043 & -0.323 & -0.229 \\
\hline Economics & 0.210 & 0.992 & 0.141 & -0.030 & 0.490 \\
\hline Statistics & -0.060 & 0.130 & -0.379 & -0.162 & 0.395 \\
\hline Engineering & -0.780 & -0.400 & -0.733 & -0.332 & -0.261 \\
\hline $\begin{array}{l}\text { Math/Computer } \\
\text { science }\end{array}$ & -0.310 & 0.542 & -0.542 & 0.050 & -0.084 \\
\hline Foreign languages & 0.715 & -0.200 & -0.327 & 0.314 & -0.309 \\
\hline Communications & 0.317 & -0.324 & 0.600 & 0.504 & -0.069 \\
\hline \multicolumn{6}{|l|}{ Final grade $(/ 110)$} \\
\hline$<95$ & -0.117 & -0.029 & -0.197 & -0.202 & -0.216 \\
\hline $95-104$ & 0.062 & -0.129 & -0.015 & 0.090 & 0.119 \\
\hline$>104$ & 0.055 & 0.159 & 0.212 & 0.112 & 0.097 \\
\hline \multicolumn{6}{|l|}{ Foreign language } \\
\hline Unable to dialogue & -1.185 & -0.406 & -0.374 & -0.548 & -0.442 \\
\hline Not fluent & 0.222 & -0.047 & 0.170 & 0.098 & 0.046 \\
\hline Fluent & 0.963 & 0.453 & 0.205 & $0.45^{1}$ & 0.397 \\
\hline \multicolumn{6}{|l|}{ Work experience } \\
\hline None & -0.399 & -0.575 & -0.652 & -0.591 & -0.732 \\
\hline $\begin{array}{l}\text { Stage/work not in } \\
\text { tourism }\end{array}$ & -0.030 & 0.002 & 0.192 & 0.007 & 0.149 \\
\hline Stage/work in tourism & 0.193 & 0.080 & 0.113 & 0.315 & 0.264 \\
\hline Work at least one year & 0.237 & 0.493 & 0.348 & 0.283 & 0.320 \\
\hline F-statistic & 13.45 & 8.065 & 6.785 & 5.841 & 6.785 \\
\hline p-value & $<0.001$ & $<0.001$ & $<0.001$ & $<0.001$ & $<0.001$ \\
\hline Multiple $\mathrm{R}^{2}$ & 0.240 & 0.159 & 0.138 & 0.121 & 0.138 \\
\hline
\end{tabular}


Considering the maximum beta estimate obtained by each attribute's level makes it possible to build the ideal profile for each job position. A receptionist, would have a degree in foreign languages (the degree in Tourism is the second best) as well as experience in the tourism sector. The administrative clerk, on the other hand, would have a degree in Economics with a high final grade (>104/110); this person would also be fluent in one or more foreign languages. The human resource professional would have a degree in Education or Psychology, be fluent in one or more foreign languages, and have work experience of at least one year, though not necessarily in the tourism sector. The web marketing specialist would have a degree in Tourism with a high final grade $(>104 / 110)$, as well as work experience of at least one year, though, once again, not necessarily in the tourism sector. Finally, the revenue manager would have a degree in Tourism with a high final grade (>104/110) and work experience of at least one year (not necessarily in the tourism sector).

Estimates obtained from the OLS models (Table 6) confirm the main results of the choice-based conjoint analysis experiment. These results are not commented on because it would repeat information already provided. In addition, the rating conjoint experiment was applied mainly as confirmation of the results of the choice-based experiment.

These outcomes show that those who share the responsibilities of recruitment in accommodation facilities are aware of what university titles imply in terms of competencies.

\section{Discussion and conclusions}

The importance of HR in tourism has gradually imposed itself, both in the literature and on the awareness of entrepreneurs (Baum, 2019; Baum et al., 2016; Elsharnouby \& Elbanna, 2021; Marques, Correia \& Costa, 2018). Entrepreneurs have become increasingly attentive to professionalism in the selection phase of recruitment; universities have become more careful in providing knowledge and skills in line with the new needs of the labour market (Hsu, Xiao \& Chen, 2017; Ruetzler et al., 2014; Sharma, 2019).

In this paper, we present the results of a survey carried out with 218 managers of the accommodation sector; they were asked to express their preferences in relation to four hypothetical profiles of candidates for five different job positions. For data collection, a conjoint design was applied, aimed at eliciting the characteristics of the ideal candidates for the considered job positions. The conjoint experiment presented in this paper required longer time than traditional surveys based on simpler questionnaires, but it produced more informative outcomes, as the task of choosing a preferred alternative is similar to what is actually done in the recruitment process.

A study of the perspectives of entrepreneurs who are selecting candidates for job vacancies may help bridge the gap between higher education and labour market; thus, the main objective of our research was to investigate which characteristics employers value the most when they recruit graduates in the accommodation sector.

The main findings show that the managers of the accommodation sector are able, in general, to associate applicants' competencies with vacancies. Consequently, it can be stated that entrepreneurs are aware of the competencies the titles of university degree programmes imply. Recruitment in accommodation facilities looks at specialized skills and academic programmes appropriate for specific job positions. One main goal was to discriminate between different academic programmes and assess whether a curriculum in tourism could meet the respondents' requirements, or, conversely, whether a specific specialization was preferred for a specific job position. The results strengthen the importance 
of the degree programme for all job positions examined in the survey; a preference for graduates in Tourism is indicated in the case of web specialist, revenue manager and receptionist, while a degree in Economics is preferred for the administrative clerk, and a degree in Education/Psychology for the position of human resource professional. This confirms the results in Humburg and Van der Velden (2015), where the real advantage for hiring seems to be the complete correspondence between the degree programme and the position to be held (e.g. a marketing degree for a position in marketing); this is explained by the expectation of companies to reduce training interventions to a minimum. However, in the mentioned study, an imperfect answer to the required qualification is compensated by at least one year of work experience. A similar result emerges in our study, with reference to all positions considered, which confirms how, in general, professional expertise is associated with a higher probability to be employed (Allen \& Van der Velden, 2011; Humburg \& Van der Velden, 2013, 2015).

Results also show that recruiters can discriminate among academic degrees shown on CVs and evaluate the adequacy of degree titles for recruitment purposes and of other educational and experiential characteristics of graduates. No importance is attributed to degree level and to willingness to travel. This result is also largely in line with the research by Humburg and Van der Velden (2015); moreover, in the 2015 study, there were no substantial differences between the degree levels, although with some slight differences between the countries considered in the survey: in Italy for junior positions a first level degree seems to be preferred.

With reference to the graduation mark, the results of our study show that high degree grades are preferred for the more technical roles. On this point, the existing literature does not provide univocal results: Ruetzler, Baker, Reynolds, Taylor and Allen, (2014) found that the graduation mark was only important if it was in the top bracket. In Humburg and Van der Velden (2015), final grade seems to weigh more for some junior, but very qualified, positions. In other research (Baker \& McGregor, 200o), it seems that a higher grade is always preferred to a lower one. Finally, a fluent command of English is very important for all the job positions considered.

The findings of this study provide insights for some specific job positions whereas other studies were mostly concerned with the preferences of employers during a planned or recently performed hiring. Furthermore, thanks to the five job positions considered, some considerations on the long-standing debate between technical and generic skills for the qualification of HR in tourism can be made.

The transversal competence of a receptionist is confirmed, consistent with the wide range of activities they perform (Baronene, 2010), for which extensive and general knowledge are required, among which the knowledge of foreign languages stands out. This explains the preference attributed to the degree in tourism, which testifies the importance of knowledge of the sector.

Regarding the position of revenue manager, the recruiters' choice of a degree in Tourism or Economics, together with knowledge of a foreign language and experience, seems to confirm the increasing role of strategy and professionalism in a profile that is not merely operational (Abrate \& Viglia, 2016).

The profile of the human resource professional is consistent with a communicative and motivating role rather than with HR management tasks that still concern a few organizations (i.e., the more structured ones). This explains the preference for a humanistic degree with knowledge not necessarily related to tourism. In addition, the lesser importance attributed to language skills and final grade comparative to the other job positions, shows a widespread underdevelopment of HR activities across the organizations considered in the survey. 
The job of administrative clerk requires specialized knowledge even if not rooted in the hospitality sector. This fact is explained by the clear preference for a degree in Economics.

Finally, when the specialist is faced with specific peculiarities of the sector, as in the case of the web marketing specialist, technical knowledge gives way to more general knowledge: degree in Tourism or Communication, supported by fluent English, a high final grade as well as previous experience.

The experiment carried out in this study also gives some suggestions to address the skills of graduates and for designing academic programmes more effectively. In particular, a high skill in foreign languages might enable a preference for graduates in tourism, even for the receptionist position. A study of the perspectives of entrepreneurs who select candidates for job vacancies and of the possibly inadequate competencies of graduates who apply for these vacancies may help bridge the gap between higher education and the labour market, trying to anticipate the skills needed in future markets. Universities can play a central role in this, being at the heart of the so-called knowledge triangle of education, research and innovation. In addition, entrepreneurs can participate from a concurrent perspective in addressing educational policies, in anticipating future skills and markets and in sustaining graduates in their employment. Conversely, owing to the structure of the curriculum in Tourism, it seems more difficult to provide specific skills for competing with a degree in Economics.

To the best of our knowledge, this is the first research paper to carry out an experiment with a choicebased conjoint methodology to examine managers' decisions in selecting graduates for job positions in tourism. This is particularly relevant due to the fact that there is still very little research on what employers prefer when hiring in the tourism sector. In fact, the literature focuses on skills required in the sector, but when employers make a selection, they are faced with an already predefined set of skills that candidates developed with study and experience: these "skills-packages" must adapt to the mix of job-related requirements. Knowing which package employers prefer is extremely important both for adapting educational and professional paths in order to increase the employability of graduates and to ensure the necessary development for tourism companies, by having adequate profiles available. The lack of knowledge explains the gaps that exist between the expectations of work in tourism and the skills provided by the university (Jaykumar, Leena \& Kandappan, 2014; Lupu, Tănase, \& Nica, 2014; Shariff et al., 2014; Vodenska \& Mileva-Bozhanova, 2017) as well as the not yet strategic role of HR in tourism (Baum, 2015; Baum et al. 2016).

The main limitations of this study are concerned with the reference population (accommodation structures of Tuscany). The high number of non-responses that occurred is not a real drawback as many refusals or incomplete data are justified by the fact that many accommodation facilities do not provide the job positions presented in the experiment.

These findings can be the starting point for future research concerning the assessment of the skills provided by degree programmes in Tourism and a comparison with other educational programmes, for instance, the fifth level in the related European qualifications system or the secondary school diploma. In fact, the non-significance of the degree level indicates consideration of non-academic programmes as well.

\section{References}

Abduljabbar Al-Taai, M.H. (2019). Effect of employees' abilities on successful ICT Application and Sustainable Development Goals: a descriptive study in hospitality organizations in Iraq. African Journal of Hospitality, Tourism and Leisure, 8(5), 1-13. 
Abrate, G., \& Viglia, G. (2016). Strategic and tactical price decisions in hotel revenue management. Tourism Management, 55, 123-132.

Airey D. (2008). Tourism education life begins at 40. Téoros, 27(1), 27-32.

Akrivos, C., Ladkin, A., \& Reklitis, P. (2007). Hotel managers' career strategies for success, International Journal of Contemporary Hospitality Management. 19(2), 107-119.

Altarawneh, G. (2016). An empirical evaluation of accounting graduates' employability skills from Jordanian employers' perspective. International Business Research, 9(1), 55-65.

Anderson, C.K., Kimes, S. \& Carrol, B. (2009). Teaching Revenue Management at the Cornell University School of Hotel Administration. INFORMS Transactions on Education, 9(3), 109-116.

Anderson, C. K., \& Xie, X. (2010). Improving Hospitality Industry Sales. Twenty-Five Years of Revenue Management. Cornell Hospitality Quarterly, 51(1), 53-67.

Andrews, J., \& Higson, H. (2008). Graduate employability,'soft skills' versus 'hard' business knowledge: A European study. Higher education in Europe, 33(4), 411-422.

Ang, S., Van Dyne, L., Koh, C., Ng, Y., Templer, K., Tay, C., \& Chandrasekar, N. A. (2007). Cultural intelligence: its measurement and effects on cultural judgment and decision making cultural adaptation and task performance. Management and Organization Review, 3(3), 335-371.

Ankor, J. (2012). The Complexities of Experience: a Critical Tourism Response, Journal of Hospitality and Tourism Management, 19(1), 1-7.

Aydin, M. D., Leblebici, N. D., Arslan, M., Kilic, M., \& Oktem, M. K. (2005). The impact of IQ and EQ on pre-eminent achievement in organizations: implications for the hiring decisions of HRM specialists. International Journal of Human Resource Management, 16(5), 701-719.

Ballantyne, R., Packer, J., \& Axelsen, M. (2009). Trends in tourism research. Annals of Tourism Research, 36(1), 149-152.

Baronene, S. (2010). Front Office: role positions and risks of maintaining standards of service quality. Perspectives of Innovations, Economics and Business, 4(1), 8o-81.

Batinić, I. (2015). The role and importance of internet marketing in modern hotel industry, Journal of Process Management - New Technologies, 3(3), 34-38.

Baum, T. (2006). Reflections on the nature of skills in the experience economy: challenging traditional skills models in hospitality. Journal of Hospitality and Tourism Management, 13(2), 124-135.

Baum, T. (2007). Human resources in tourism: Still waiting for change. Tourism Management, 28(6), 1383-1399.

Baum, T. (2015). Human resources in tourism: Still waiting for change? - A 2015 reprise. Tourism Management, 50, 204-2012.

Baum, T. (2019), Does the hospitality industry need or deserve talent? Hospitality Industry, 31(10), 38233837.

Baum, T., Kralj, A., Robinson, R. N., \& Solnet, D. J. (2016). Tourism workforce research: A review, taxonomy and agenda. Annals of Tourism Research, 6o, 1-22.

Baum, T., \& Odgers, P. (2001). Benchmarking Best Practice in Hotel Front Office: The Western European experience. Journal of Quality Assurance in Hospitality and Tourism, 2 (3/4), 93 -109.

Baum, T., \& Szivas, E. (2008). HRD in tourism: A role for government? Tourism Management, 29(4), 783-794.

Bharwani, S., \& Jauhari, V. (2013). An exploratory study of competencies required to co-create memorable customer experiences in the hospitality industry. International Journal of Contemporary Hospitality Management, 25(6), 823-843.

Biesma, L.G., Pavlova, M., von Merode, G.G. \& Groot, W. (2007). Using conjoint analysis to estimate employers' preferences for key competencies of master level Dutch graduates entering the public health field. Economic for Education Review, 26(3), 375-386. 
Bitner, M. J., Booms, B. H., \& Tetreault, M. S. (1990). The service encounter: Diagnosing favorable and unfavorable incidents, Journal of Marketing, 54(1), 71-84.

Brewster, C., Farndale, E., \& von Ommeren, J. (2000). HR Competencies and Professional Standards. Cranfield: World Federation of Personnel Management Associations.

Bridgstock, R. (2009). The graduate attributes we've overlooked: enhancing graduate employability through career management skills. Higher Education Research \& Development, 28(1), 31-44.

Carbone, L. P. \& Haeckel, S. H. (1994). Engineering customer experiences. Marketing Management, 3(3), 8-19.

Carmone, F., Green, P. E., \& Jain, A. K. (1978). Robustness of conjoint analysis: Some Monte Carlo results. Journal of Marketing Research, 15, 300-303.

Casalo, L. V., Flavian, C., Guinaliu, M., \& Ekind, Y. (2015). Do online hotel rating schemes influence booking behaviors? International Journal of Hospitality Management, 49, 28-36.

Cattin, P., \& Wittink, D. (1982). Commercial use of conjoint analysis: A survey. Journal of Marketing, 46, 44-53.

Cegarra-Navarro, J. G., Martinez-Martinez, A., Ortega Gutiérrez. J., \& Leal Rodríguez, A. L. (2013). Environmental knowledge, unlearning, and performance in hospitality companies. Management Decision, 51(2), 341-360.

Cetin, G., Demirciftci, T., \& Bilgihan, A. (2016). Meeting revenue management challenges: Knowledge, skills and abilities. International Journal of Hospitality Management, 57, 132-142.

Chaffey, D., Ellis-Chadwick, F., Mayer, R., \& Johnston, K. (2009). Internet Marketing: Strategy, Implementation and Practice. 4th Edition. New Jersey: Prentice Hall.

Chiru, C., Ciuchete, S.G., Lefter, G.G., \& Paduretu, E. (2012). A cross country study on university graduates key competencies. An employer's perspective. Procedia - Social and Behavioral Sciences, 46, 4258-4262.

Chou, C. J., \& Chen, P.C. (2014). Preferences and willingness to pay for green hotel attributes in tourist choice behavior: The case of Taiwan. Journal of Trave/ E Tourism Marketing, 37(8), 937-957.

Christou, E.S. (1999). Hospitality management education in Greece. An exploratory study, Tourism Management, 20(6), 683-691.

Chung-Herrera, B. G., Enz, C. A., \& Lankau, M. J. (2003). Grooming future hospitality leaders: a competencies model. The Cornell Hotel and Restaurant Administration Quarterly, 44(3), 17-25.

Cobanoglu, C., Dede, P. \& Poorani, A. (2007). An Analysis of Skills and Competencies of Full Service Hotel Technology Managers. Journal of Teaching in Travel E Tourism, 6(4), 19-35.

Coles, T., Fenclova E., \& Dinan, C. (2013). Tourism and corporate social responsibility: A critical review and research agenda. Tourism Management Perspectives, 6, 122-141.

Connolly, P., \& McGing, G. (2006). Graduate education and hospitality management in Ireland. International Journal of Contemporary Hospitality Management, 18(1), 50-59.

De Fillippi, R. J., \& Arthur, M. B. (1994). The boundaryless career: a competency-based perspective. Journal of Organizational Behavior, 15(4), 307-324.

De Shazo, J. \& Fermo, G. (2002). Designing choice sets for stated preference methods: The effects of complexity on choice consistency. Journal of Environmental Economics and Management, 44,123-143

De Vos, A., \& Soens, N. (2008). Protean attitude and career success: the mediating role of selfmanagement. Journal of Vocational Behavior, 73(3), 449-456.

Di Stasio, V. (2014). Education as a signal of trainability: Results from a vignette study with Italian employers. European Sociological Review, 30(6), 796-809.

Earley, P.C., \& Ang, S. (2003). Cultural Intelligence: Individual Interactions Across Cultures. Palo Alto: Stanford University Press.

Elsharnouby, T.H., Elbanna, S. (2021). Change or perish: Examining the role of human capital and dynamic marketing capabilities in the hospitality sector. Tourism Management, 82, 1-13. 
Fabbris, L., Scioni, M., \& Vaglini, B. (2015). The ideal candidate to a job through a conjoint study. In: Academic Proceedings 2015 University-Industry Interaction Conference: Challenges and Solutions for Fostering Entrepreneurial Universities and Collaborative Innovation, UIIN - University Industry Innovation Network, Science Marketing, 117-133 (ISBN: 978-94-91901-15-7)

Gammie, B., Gammie, E. \& Cargill, E. (2002) Personal skills development in the accounting curriculum. Accounting Education: an international journal, 11(1), 63- 78.

Garbin Praničević, D. \& Mandić, Ante (2020) ICTs in the hospitality industry: An importanceperformance analysis among small family-owned hotels. Tourism, 68(2), 221-223.

Giusti, A., \& Grassini, L. (2017). Lauree e Lauree Magistrali in ambito turistico. Turistica, XXVI, 5-36, ISSN:1974-2207.

Goleman, D. P. (1995). Emotional Intelligence: Why It Can Matter More Than IQ for Character, Health and Lifelong Achievement. New York: Bantam Books.

Gonzalez, R., Gasco, J. \& Llopis, J. (2019). ICTs in hotel management: a research review. International Journal of Contemporary Hospitality Management, 31(9), 3583-3609.

Green, P. E., \& Srinivasan, V. (1978). Conjoint analysis in consumer research: issues and outlook. Journal of Consumer Research, 5(2), 103-123.

Harris. P. J., \& Mongiello, M. (2001). Key performance indicators in European hotel properties: general managers' choices and company profiles. International Journal of Contemporary Hospitality Management, 13(3), 120-128.

Hartman, D. B., Bentley, J., Richards, K., \& Krebs, C. (2005). Administrative Tasks and Skills Needed for Today's Office: The Employees' Perspective. Journal of Education for Business, 8o(6), 347-357.

Hochschild, A. R. (1983). The managed heart: Commercialisation of human feeling. Berkley: University of California Press.

Hsu, C. H. C., Xiao, H., \& Chen, N. (2017). Hospitality and tourism education research from 2005 to 2014 : Is the past a prologue to the future? International Journal of Contemporary Hospitality Management, 29(1), 141-160.

Humburg, M. \& van der Velden, R. (2013). What is expected of higher education graduates in the 21st century? ROA Research Memorandum, ROA-RM-2013/13. Research Centre for Education and the Labour Market, Maastricht University.

Humburg, M. \& van der Velden (2015). Skills and the graduate recruitment process: Evidence from two discrete choice experiments. Economics of Education Review, 49(re2015), 24-41.

Ip, C., Leung, R. \& Law, R. (2011). Progress and development of information and communication technologies in hospitality. International journal of contemporary hospitality management, 23(4), 533-551.

IRPET (2019). Rapporto sul turismo in Toscana. IRPET (Istituto per la Programmazione Economica della Toscana). Retrieved from: http://www.irpet.it/wp-content/uploads/2019/o6/rapporto_turismo_ toscana_2019-1.pdf (accessed May, 2020).

Jackling B. \& De Lange P, (2009). Do accounting graduates' skills meet the expectations of employers? A matter of convergence and divergence, Accounting Education, 18 (4-5), 369-385.

Jaykumar, V., Leena, N. F. \& Kandappan B. (2014). Hotel managers' perspective of managerial competency among graduating students of hotel management programme. Procedia - Social and Behavioral Sciences, 144, 328 - 342.

Johnson, M. (1987). The body in the mind: The bodily basis of meaning, imagination and reason. Chicago: University of Chicago Press.

Kay, C., \& Russette, J. (200o). Hospitality-management competencies: Identifying Managers essential skills. Cornell Hotel and Restaurant Administration Quarterly, 41(2), 52-63. 
Khetjenkarn, S. \& Agmapisarn, C. (2020). The effects of emotional labour on the outcomes of the job and the organization: Do the differences in age and the manager's emotional intelligence have any impact in the hotel business? European Journal of Tourism Research, 25, 2504, 1-26

Kimes, S. E. (1989). The basics of yield management. Cornell Hotel and Restaurant Administration Quarterly, 30(3), 14-19.

Kimes, S. E., \& Wirtz, J. (2002). Perceived fairness of demand-based pricing for restaurants. Cornell Hotel and Restaurant Administration Quarterly, 43(1), 31-37.

Kimes, S. E. (2011). The future of hotel revenue management. Journal of Revenue and Pricing Management, 10(1), 62-72.

Kong, A. P.-K. (2015). The dilemma facing higher education and industry in tourism and hospitality. SpringerPlus, 4 (Suppl 2), 1-2.

Kučerová, J., Gúčik, M. (2017). Reflections over the past and present research and higher education on tourism in Czechoslovakia and Slovakia. European Journal of Tourism Research, 15, 38-51

Kuhfeld, W., Randal D. T., \& Garratt, M. (1994). Efficient Experimental Designs with Marketing Research Applications. Journal of Marketing Research, 31, 545-57.

Ladkin, A. (2011). Exploring tourism labor. Annals of Tourism Research, 38(3), 1135-1155.

Ladkin, A., \& Juwaheer, T. D. (2000). The career paths of hotel general managers in Mauritius. International Journal of Contemporary Hospitality Management, 12(2), 119-125.

Lent, R. W., Brown, S. D., \& Hackett, G. (1994). Toward a unifying social cognitive theory of career and academic interest, choice, and performance. Journal of Vocational Behavior, 45(1), 79-122.

Lindberg, K., \& Veisten, K. (2012). Local and non-local preferences for nature tourism facility development. Tourism Management Perspectives, 4, 215-222.

Louviere, J. J., Hensher, D. A., \& Swait, J. D. (2000). Stated choice methods: analysis and applications. Cambridge: Cambridge university press.

Lupu N., Tănase M.O., \& Nica A.-M. (2014). Perception about business education in the tourism domain and the hospitality industry. Business Education in the Tourism Domain and the Hospitality Industry, XVI (37), 800-811

Mariani, P., Marletta, A. \& Zenga, M. (2019). What Do Employers Look for When Hiring New Graduates? Answers from the Electus Survey. Petrucci, A., Racioppi, F. \& Verde R. (eds), New Statistical Developments in Data Science, Springer Proceedings in Mathematics and Statistics, Springer, 359372.

Marques, G.S., Correia, A., \& Costa, C.M. (2018). The influence of customer orientation on emotional labour and work outcomes: a study in the tourism industry, European Journal of Tourism Research, 20, 59-77.

McFadden, D. (1974). Conditional logit analysis of qualitative choice behavior. In Zaremka, P., Frontiers in econometrics, New York: Academic Press, 105-142.

Mitchell, T., \& Strauss J. (2001). Practitioner and Academic Recommendations for Internet Marketing and E-Commerce Curricula. Journal of Marketing Education, 23(2), 91-102.

Mohamed, E. K. \& Lashine, S. H. (2003) Accounting knowledge and skills and the challenges of a global business environment. Managerial Finance, 29(7), 3-16.

Moscardo, G., \& Benckendorff, P. (2015). Education for sustainability in tourism: a handbook of processes, resources, and strategies. Heidelberg, Germany: Springer.

Munar, A. M., \& Montano, J. J. (2009). Generic competences and tourism graduates. Journal of Hospitality, Leisure, Sports and Tourism Education, 8(1), 70-84.

Ng, W. C., \& Pine, R. (2003). Women and men in hotel management in Hong Kong: perceptions of gender and career development issues. International Journal of Hospitality Management, 22(1), 85102. 
Nickson, D., Baum, T., Losekoot, E., Morrison, A., \& Frochot, I. (2003). Skills organizational performance and economic activity in the hospitality industry. A literature review. SKOPE Monograph. UK: University of Oxford and Warwick.

Noone, B. M., McGuire, K. A., \& Rohlfs, K. V. (2011). Social media meets hotel revenue management: Opportunities, issues and unanswered questions. Journal of Revenue and Pricing Management, 10(4), 293-305.

Pfeffer, J. (1994). Competitive Advantage through People, California Management review, 36(2), 9-28.

Phillips, P., \& Louvieris, P. (2005). Performance Measurement Systems in Tourism, Hospitality, and Leisure Small Medium-Sized Enterprises: A Balanced Scorecard Perspective. Journal of Travel Research, 44(2), 201-211.

Pine, B., \& Gilmore, J. H. (1999). The Experience Economy. Boston: Harvard Business School Press.

Poole, M., \& Jenkins, G. (1997). Responsibilities for human resource management practices in the modern enterprise: evidence from Britain. Personnel Review, 26(5), 333-56.

Purohit, G., \& Purohit, D. (2013). From Customer Satisfaction to Customer Delight: A New Trend in Hospitality Industry. Global Journal of Management and Business Studies, 3(5), 545-548.

Ritzer, G. (2004). The McDonaldization of society (Rev. ed.). Thousand Oaks: Pine Forge Press.

Ruetzler, T., Baker, W., Reynolds, D., Taylor, J. \& Allen, B. (2014). Perceptions of technical skills required for successful management in the hospitality industry-An exploratory study using conjoint analysis. International Journal of Hospitality Management, 39, 157-164. DOI: 0.1016/j.ijhm2014.02.012

Sardo, F., Serrasqueiro, Z., \& Alves, H. (2018). On the relationship between intellectual capital and financial performance: A panel data analysis on SME hotels. International Journal of Hospitality Management, 75, 67-74

Sawtooth Software, (2017). The CBC system for Choice-Based Conjoint analysis, Version 9, Technical paper, Sawtooth software Inc., Retrieved from: https://www.sawtoothsoftware.com/ download/techpap/cbctech.pdf (accessed April 2019).

Schneider, B., Hayes S. C., Lim B. C., \& Raver J. L. (2003). The human side of strategy: Employee experiences of strategic alignment in a service organization. Organizational Dynamics, 32(2), 122-41.

Sewell, P., \& Dacre Pool, L. (2010). Moving from conceptual ambiguity to operational clarity: employability, enterprise and entrepreneurship in higher education. Education + Training, 52(1), 8994.

Shariff, N.M., Kayat, K., \& Abidin, A.Z. (2014). Tourism and hospitality graduates competencies: Industry perceptions and expectations in the Malaysian perspectives. World Applied Sciences Journal, 31(11), 1992-2000.

Shaw, G., \& Williams, A. M. (1994). Critical Issues in Tourism: A geographical perspective. Oxford: Blackwell Publishers.

Sincoff, M. Z. \& Owen, C. L. (2004). Content Guidelines for an Undergraduate Human Resources Curriculum: Recommendations from Human Resources Professionals. Journal of Education for Business, 8o(2), 8o-85.

Singal, M. (2014). Corporate social responsibility in the hospitality and tourism industry: Do family control and financial condition matter? International Journal of Hospitality Management, 36(1), 8189.

Smith, B., Maguire, W., \& Han, H.H. (2018). Generic skills in accounting: perspectives of Chinese postgraduate students. Accounting and Finance, 58, 535-559.

Studnička, P. \& Plzáková, L. (2017). Connections between scientific research and education in the field of tourism and leisure in the Czech Republic. European Journal of Tourism Research, 15, 24-37.

Sun, S., Law, R., \& Zhang, M. (2019). An updated review of tourism-related experimental design articles. Asia Pacific Journal of Tourism Research. DOI: 10.1080/10941665.2019.1699128 
Torugsa, N.A., O’Donohue W. \& Hecker, R. (2013). Proactive CSR: An Empirical Analysis of the Role of its Economic, Social and Environmental Dimensions on the Association between Capabilities and Performance. Journal of Business Ethics, 11(2), 383-402.

Ulrich, D. (1987). Organizational capability as a competitive advantage: Human resource professionals as strategic partners. Human Resource Planning, 10(4), 169-184.

Ulrich, D., Brockbank, W., Yeung, A. K., \& Lake D.G. (1995). Human Resource Competencies: An Empirical Assessment. Human Resource Management, 34(4), 473-495.

Upchurch, R. S., Ellis, T., \& Seo, J. (2004). Applying the hierarchical cluster analysis procedure upon the process of yield management: a comparative study. Journal of Travel E Tourism Marketing, 16(4), 4758.

van der Velden, R. \& Allen, J. (2011). The Flexible Professional in the Knowledge Society: Required Competences and the Role of Higher Education. In Allen, J. \& van der Velden, R. (eds.), The Flexible Professional in the Knowledge Society, Springer, Dordrecht, 15-53.

Vallen, G.K. \& Vallen, J.J. (200o). Check in, Check out: Front office management, $6^{\text {th }}$ edn, Prentice-Hall, Upper Saddle River, NJ.

Varela González, J., \& García Gorazo, T. (2006). Structural relationships between organizational service orientation, contact employee job satisfaction and citizenship behaviour. International Journal of Service Industry Management, 17(1), 23-50.

Villosio, C. (2010). What makes a good candidate? The preferences of HR Managers about new graduated job-seekers. Giornale degli Economisti e Annali di Economia, 6o(3), 97-117.

Vodenska, M. \& Mileva-Bozhanova, S. (2017). Sixty years of tourism higher education and research in Bulgaria. European Journal of Tourism Research, 15, 64-74.

Warhurst, C., Nickson, D., Witz, A., \& Cullen, A. M. (2000). Aesthetic labour in Interactive service work: Some case study evidence from the 'New Glasgow'. Service Industries Journal, 20(3), 1-18.

Wessels, W., Du Plessis E., \& Slabbert E. (2017). Key competencies and characteristics of accommodation managers. SA Journal of Human Resource Management, 15, 1-11.

Westwood, A. (2002). Is new work good work? London: The Work Foundation.

Westwood, A. (2004). Skills that matter and shortages that don't. In Warhurst, C., Grugulis, I., \& Keep E. (Eds.), The skills that matter, 38-54. Basingstoke: Palgrave.

Wood, R. C. (1997). Working in Hotels and Catering. London: International Thomson Business Press.

Zopiatis, A., \& Constanti, P. (2007). And never the twain shall meet. Investigating the hospitality industry-education relationship in Cyprus. Education + Training, 49(5), 391-407.

Received: 01/07/2020

Accepted: 07/01/2021

Coordinating editor: Stanislav Ivanov 